\title{
Impact of climate warming on vegetation cover and permafrost in West Siberia northern taiga
}

\author{
N. G. Moskalenko
}

Earth Cryosphere Institute, Siberian Branch of the Russian Academy of Science, Tyumen, Russia; nat-moskalenko@yandex.ru

Received 4 December 2012; revised 3 January 2013; accepted 18 January 2013

\section{ABSTRACT}

The goal of this study is to reveal the impact of climate warming on vegetation and permafrost in ecosystems of West Siberia permafrost zone. Changes of various ecosystem componentsmicrorelief, vegetation and soil covers, active layer thickness, soil and permafrost temperature, exogenous geological processes-are investigated. The impact of increase of air temperature and the amount of atmospheric precipitation on the development of northern taiga ecosystems is monitored. Results of ecosystem changes under the impact of climatic changes are presented. The ecosystems are detected, in which the local permafrost temperature decrease caused by dynamics of vegetation cover observed on a background of the general tendency of temperature increase.

Keywords: Climate Change; Ecosystem; Landscape; Permafrost; Vegetation; Soil

\section{INTRODUCTION}

The warming of an observable climate from the end of 20th century was accompanied by vegetation and permafrost changes, is especially in the zone of sporadic permafrost. This important problem is examined in works of many researchers [1-17]. They demonstrated that freezing and thawing conditions change in response to the vegetation dynamics. Increases in moss and lichen cover thickness result in the reduction of active layer thickness, and decreases in soil and ground temperatures. However, in these works not enough attention was given to estimated impact of climate on the vegetation and permafrost in the ecosystems. In the present report the author tries to fill this deficiency based on long-term monitoring of changes in the northern taiga ecosystem of Western Siberia.

\section{LOCATION AND OBSERVATIONS}

Research on ecosystems was carried out since 1970 on the Nadym stationary site (Figure 1) located $30 \mathrm{~km}$ to a southeast from the town of Nadym [18] in the zone of sporadic permafrost distribution [19]. Patches of permafrost, occupying up to $50 \%$ of areas, are closely associated with peatlands, peat bogs, and frost mounds of third fluvial-lacustrine plain having elevations ranging from 25 to $30 \mathrm{~m}$. The plain is composed of sandy deposits interbedded with clays, with an occasional covering of peat [20].

Ecosystem changes are observed on 28 permanent fixed $(10 \times 10 \mathrm{~m})$ plots and transects. Observations include leveling of microrelief, estimation of species composition of vegetation cover, height and frequency of plant species, measurements of air, soil and permafrost temperatures, thickness and moisture of the active layer.

Study of spatial and temporal patterns of active layer thickness, caused with microrelief and vegetation mosaic was carried out on $100 \times 100$ m CALM (Circumpolar Active Layer Monitoring) grid. In 16 boreholes depth 10 $\mathrm{m}$ and 1 borehole depth $30 \mathrm{~m}$ were established loggers

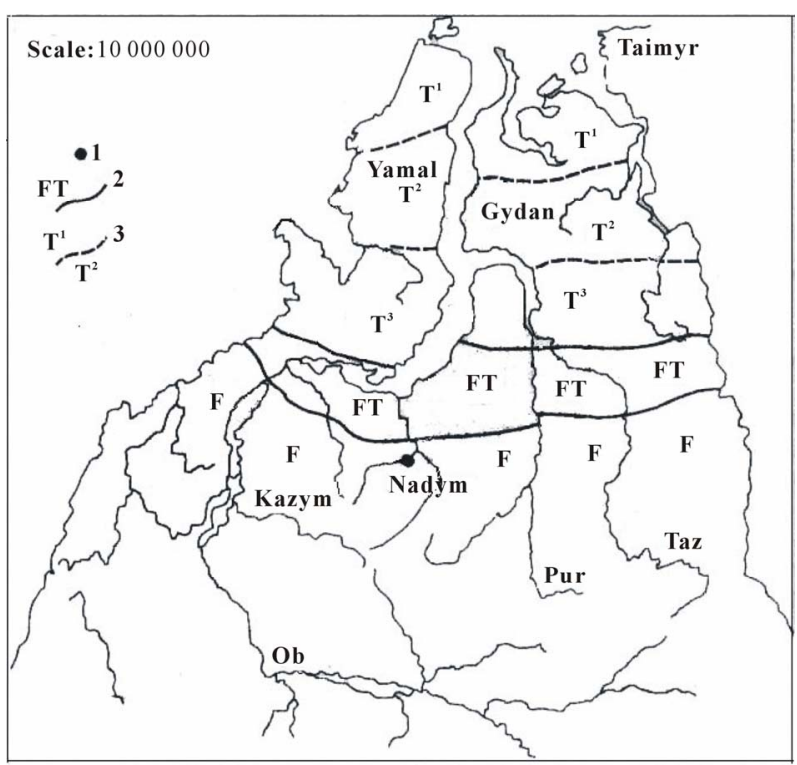

Figure 1. Location of the Nadym site. 1-site, 2-boundaries of zones ( $\mathrm{T}$ - tundra, FT - forest tundra, F-taiga), 3-boundaries of subzones ( $\mathrm{T}^{1}$-northern, $\mathrm{T}^{2}$ - typical, $\mathrm{T}^{3}$ - southern). 
Hobo, and measurements of permafrost temperature were carried out by project TSP (Thermal State of Permafrost).

\section{RESULTS}

Before during the last decades in the north of West Siberia air temperatures rose and the amount of atmospheric precipitation increased (Figures 2 and 3). In this connection the process of bog formation on flat, poorly drained surfaces of plains became more active. As a result, hummocky open woodlands with pine cloudberrywild rosemary-lichen-peat moss cover were replaced by andromeda-cotton-grass-sedge-peat moss bogs. Hummocks settled, and the lenses of permafrost under the hummocks thawed.

The frequency of wild rosemary (Ledum palustre) which dominated in a cover of the open woodland on the plot fell sharply after 1997 (Figure 4, 2).

The frequency of cotton-grass (Eriophorum polystachion) for the last decades increased (Figure 4, 1), and it began to dominate the cover.

Comparison of biomass in wood communities and bog communities shows that by bog formation in wood all aboveground biomass decreases from 2316 to $1715 \mathrm{~g} / \mathrm{m}^{2}$ (on 26\%) and biomass of graminoid and mosses increases. Comparison of species composition of wood and bog plant communities presents that biodiversity of vegetation cover in process of bogginess decreases in the result of absence mesophyte species of sedges and shrubs

$\mathrm{T},{ }^{\circ} \mathrm{C} 197019751980198519901995200020052010$

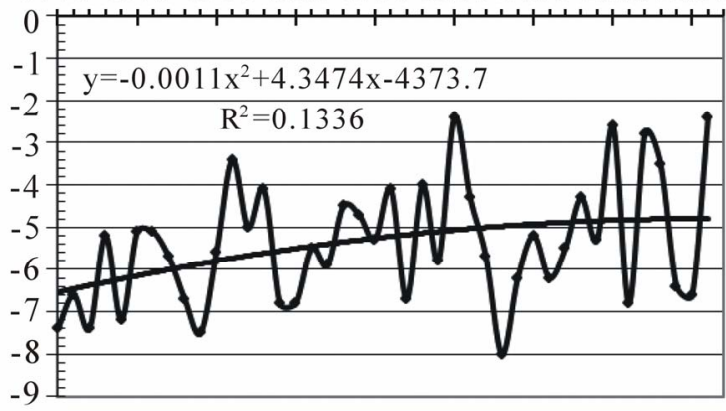

Figure 2. Mean annual air temperature $\left(\mathrm{T}^{\circ} \mathrm{C}\right)$.

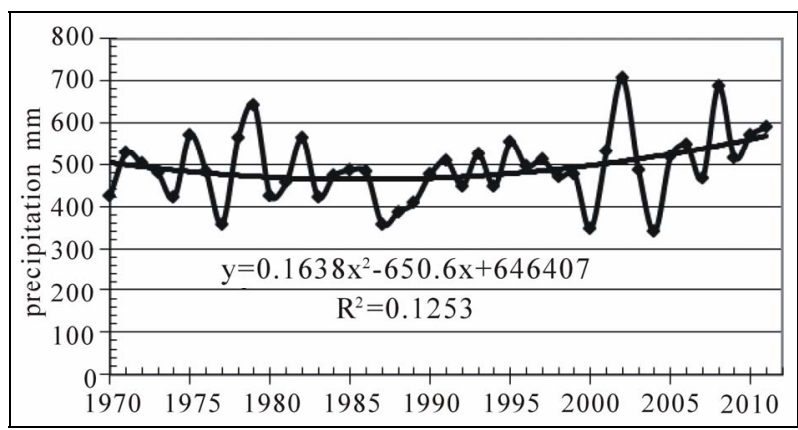

Figure 3. Annual amount of atmospheric precipitation.
(Carex globularis, Empetrum nigrum, Vaccinium vitisidaea), and also lichens (Cladina rangiferina, C. stellaris, Cetraria islandica, Cladonia coccifera). Common number of species decreases from 27 to 17 .

Considerable changes of geocryological conditions we observed on palsa peatland. According to the borehole drilling the peat thickness on our palsa peatland is $1 \mathrm{~m}$, below lies sand with layers of the clay, underlaying with depth $3.7 \mathrm{~m}$ by clay.

The analysis of the given measurements of active layer thickness on the palsa peatland has shown an increasing trend (Figure 5), as a result of the increase of the air thawing index (Figure 6). Temperature trend for 1970 to 2011 is of $0.3^{\circ} \mathrm{C}$ in a year. The thickness of the active

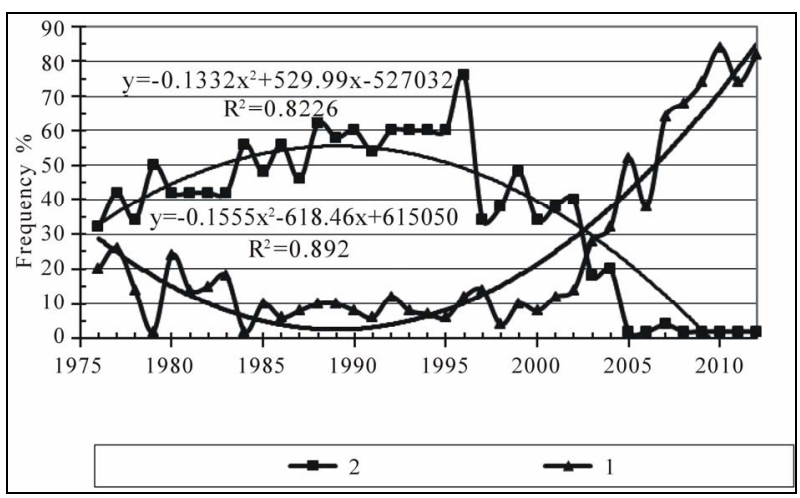

Figure 4. Frequency changes of Ledum palustre (2) and Eriophorum angustifolium (1) on flat boggy site.

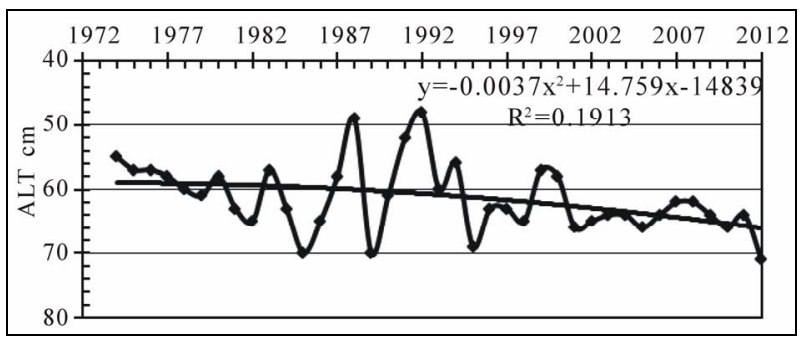

Figure 5. Active layer thickness (ALT) on the palsa peatland.

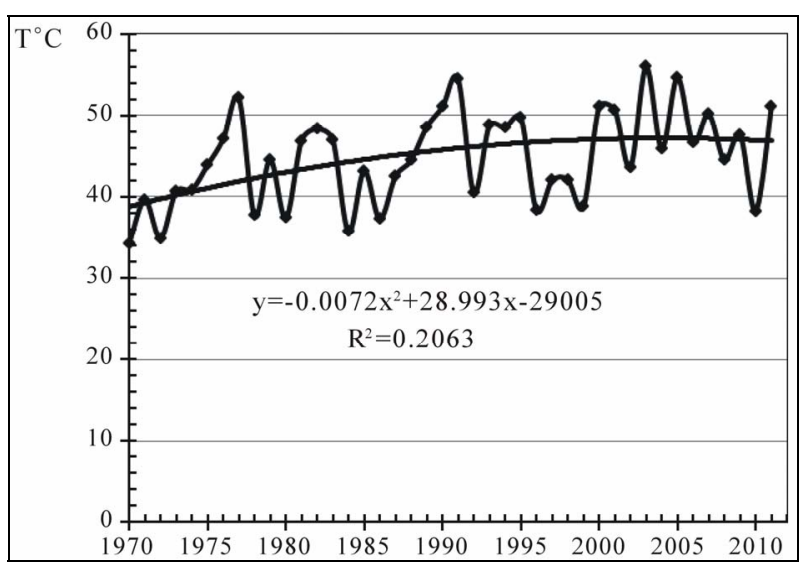

Figure 6. Air thawing index in $\mathrm{Nadym}\left(\mathrm{T}^{\circ} \mathrm{C}\right.$ month). 
layer for the period of observations increased on $30 \%$.

The analysis of permafrost temperature measurements in boreholes has shown that on palsa peatland there was marked maximal of $1.4^{\circ} \mathrm{C}$ rise. The temperature of permafrost at the depth of $10 \mathrm{~m}$ (layer with minimum annual fluctuations of temperatures) for the period of observations (Figure 7) increased from $-1.8^{\circ} \mathrm{C}$ to $-0.4^{\circ} \mathrm{C}$. The air and soil temperature increase on the palsa peatland is the likely cause for the appearance of tree species (Betula tortuosa) and rise in frequency and height of shrubs (Ledum palustre, Betula nana).

On the dwarf shrub-cotton grass-peat moss bogs in the result of vegetation dynamics it is possible to observe formation of new frost heavy hummocks presented on Figure 8.

Monitoring of frost mounds, which Olga Ponomareva [21] has been performed, shows that on young frost mound, formed in 1973 (Figure 9), surface settlement appeared in 2009 (Figure 10). In 2011 the height of frost mound top has decreased on $20 \mathrm{~cm}$ (from $65 \mathrm{~cm}$ up to 45 $\mathrm{cm})$.

On cotton grass-peat moss bogs with the lowered permafrost table on formed on it dwarf shrub-peat moss

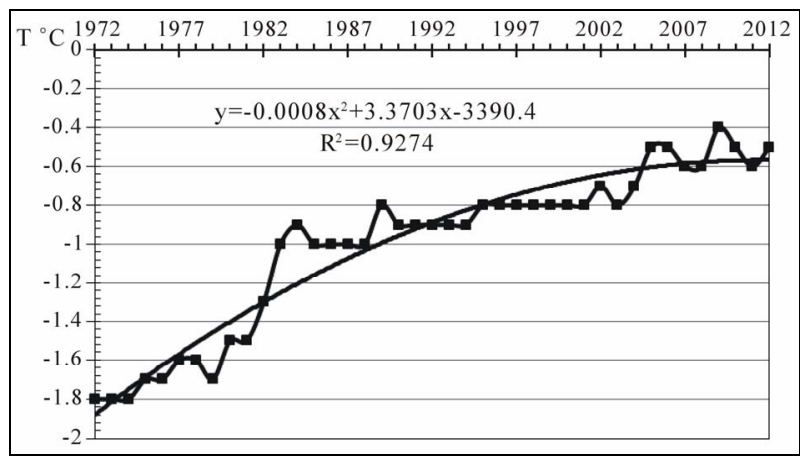

Figure 7. Permafrost temperature $\left(\mathrm{T}^{\circ} \mathrm{C}\right)$ at the depth of $10 \mathrm{~m}$ on the palsa peatland.

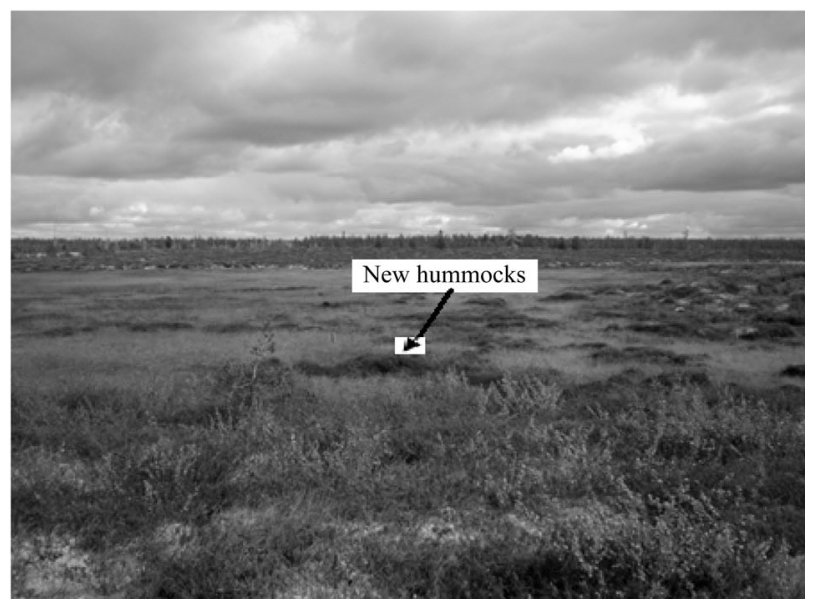

Figure 8. New frost heavy hummocks on the dwarf shrub-cotton grass-peat moss bog.

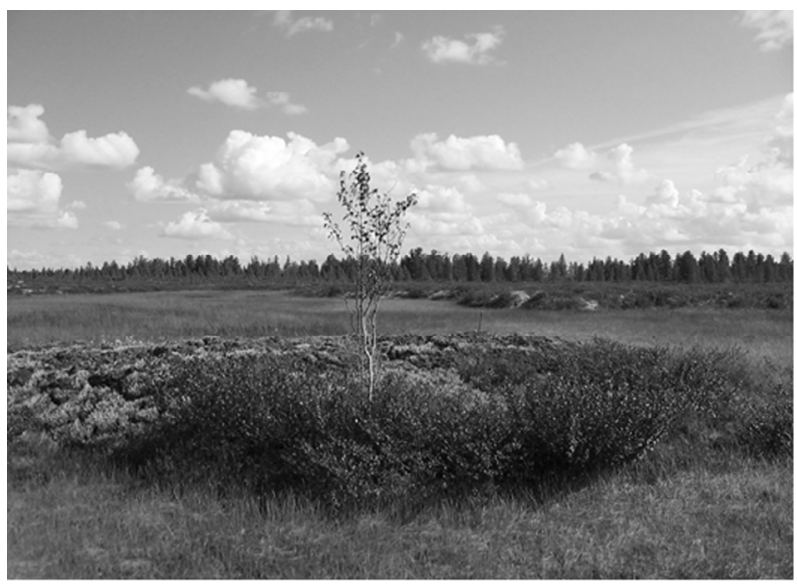

Figure 9. Young frost mound in 2003.

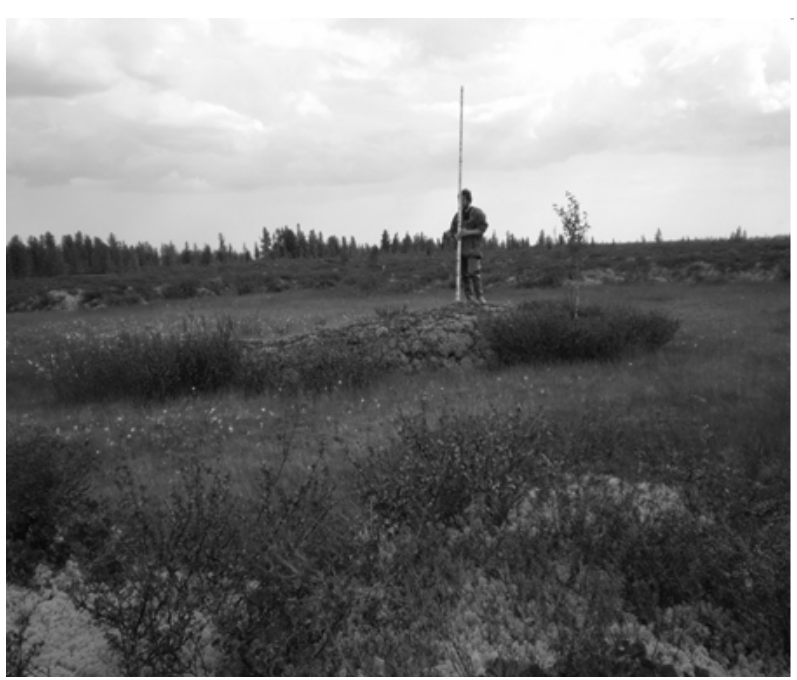

Figure 10. Young frost mound in 2009.

hummocks after cold winters it is observed formation of new frozen ground. Mean active layer thickness on these hummocks is $80 \mathrm{~cm}$. These hummocks on the bog on the Nadym CALM grid are presented.

The ecosystems are detected, in which the local temperature decrease observed on a background of the general tendency of temperature increase, caused by dynamics of the vegetation cover. It is necessary to allow a possibility of such different tendencies of temperature changes in ecosystems at for the same changes of the climate at geocrylogical monitoring.

For example, such downturn of permafrost temperatures was observed on dwarf shrub-sedge-peat moss bog, replaced through 25 years by sedge-dwarf shrub-lichenpeat moss peatland as a result of increase in moss thickness, accumulation of peat and growths of dwarf shrubs (Andromeda polifolia, Chamaedaphne calyculata). Here permafrost temperatures for the investigated period have gone down on $0.3^{\circ} \mathrm{C}$ (Figure 11).

Though in the next flat peatlands surrounding the 


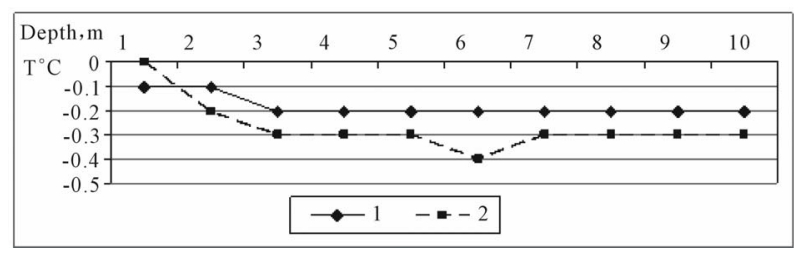

1979

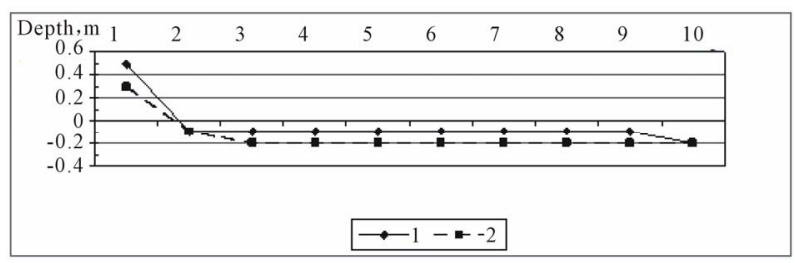

1989

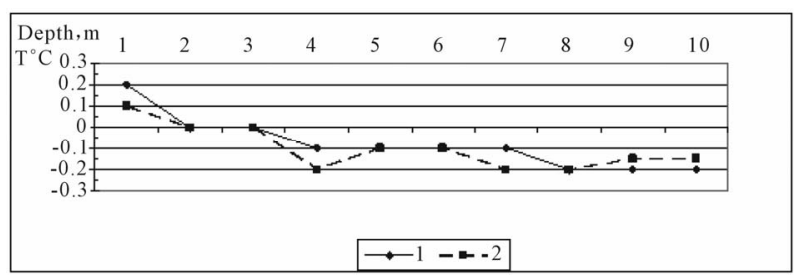

1999

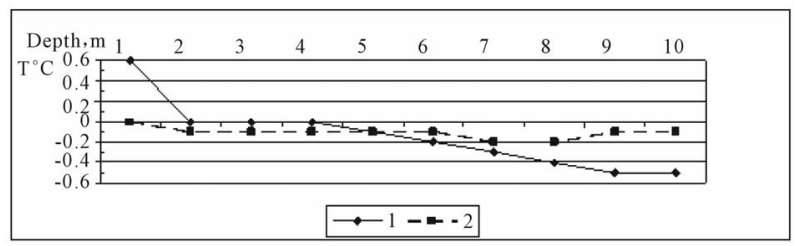

2010

Figure 11. Permafrost temperature $\left(\mathrm{T}^{\circ} \mathrm{C}\right)$ changes on the bog (1) and on the peatland (2) at the depths of $1-10 \mathrm{~m}$ in 1979,1989 , 1999 and 2010 years.

drained up bog, the permafrost temperature became higher, as we can see by comparison temperature data of drained up bog and flat peatland in 1979 and in 2010 years.

\section{CONCLUSIONS}

Long-term monitoring of the northern taiga ecosystem changes has allowed revealing impact of climatic warming on the vegetation cover dynamics and on the permafrost and its temperature.

During the last decades in the north of Western Siberia the rise in air temperature and the increase in amount of atmospheric precipitation are observed. In this connection process of bog development on flat poorly drained surfaces of plains became more active. As a result of it hummocky pine cloudberry-wild rosemary-lichen-peat moss open woodlands with lenses of permafrost under the hummocks are replaced by andromeda-cotton grasssedge-peat moss thawed bogs.

On the dwarf shrub-cotton grass-peat moss bogs in the result of vegetation dynamics it is possible to observe formation of new frost heavy hummocks.

The ecosystems are detected, in which the local permafrost temperature decrease caused by dynamics of vegetation cover observed on a background of the general tendency of temperature increase. It is necessary to allow a possibility of such different tendencies of temperature changes in ecosystems at for the same climate changes at carried out geocryological monitoring.

\section{ACKNOWLEDGEMENTS}

The research was supported by project Circumpolar Active Layer Monitoring (CALM) project (National Science Foundation, Grant NSF OPP-9732051, 0PP-0225603); Thermal State of Permafrost (TSP) project (NSF RC-0632400, ARC-0520578), and Council under grants of the President of the Russian Federation (grant NSH-5582.2012.5).

\section{REFERENCES}

[1] Tyrtikov, A.P. (1969) Impact of the vegetation cover on freezing and thawing of grounds. The Moscow State University, Moscow.

[2] Tyrtikov, A.P. (1979) Vegetation cover dynamics and evolution of permafrost elements of relief. Nauka, Moscow.

[3] Brown, J.E. and Pewe, T.L. (1973) Distribution of permafrost in North America and its relationship to the environment. "Permafrost" Second International Conference, National Academy of Sciences, Washington, 15-21.

[4] Nevecherya, V.L., Moskalenko, N.G. and Tagunova, L.N. (1975). About an opportunity of the forecast of change engineering-geocryological conditions depending on character of development of natural complexes at construction in the north of Western Siberia. Methods of geocryological research. Trudy of VSEGINGEO, 98, 16-34.

[5] Nelson, F.E., Lachenbruch, A.H., Woo, M.-K., et al. (1993) Permafrost and changing climate. Permafrost: Proceedings of the Sixth International Conference, 2, 987-1005.

[6] Ershov, E.D., Maksimova, L.N., Medvedev, A.V., et al. (1994) Reaction of permafrost to global changes of a climate. Geoecology, 5, 11-24.

[7] Pavlov, A.V. (1997) The forecast of permafrost zone evolution in the north of Western Siberia (according to monitoring). In: Results of Basic Researches of the Earth Permafrost Zone in Arctic and Subarctic Regions. Nauka, Novosibirsk, 94-102.

[8] Pavlov, A.V. (2008) Monitoring of permafrost zone. Academy izd-vo, Novosibirsk.

[9] Osterkamp, T. and Romanovsky, V. (1999) Evidence for warming and thawing of discontinuous permafrost in Alaska. Permafrost and Periglacial Processes, 10, 17-37. doi:10.1002/(SICI)1099-1530(199901/03)10:1<17::AIDPPP303>3.0.CO;2-4

[10] Parmuzin, S.J. and Chepurnov, M.B. (2001) Existential dynamics of permafrost in the European North and Western Siberia in XXI century in connection with possible 
changes of a climate. Materials of the Second Conference of Geocryologists in Russia, 2, 231-235.

[11] Izrael, J.A., Pavlov, A.V. and Anokhin, J.A. (2002) Evolution of permafrost zone at modern changes of a global climate. Meteorology and hydrology, 1, 10-18.

[12] Hollister, R.D., Webber, P.J. and Tweedie, C.E. (2005) The response of Alaskan arctic tundra to experimental warming: Differences between short- and long-term responses. Global Change Biology, 1, 11-12.

[13] Walker, M.D., Wahren, C.H., Hollister, R.D., et al. (2005) Plant community responses to experimental warming across the tundra biome. Proceedings of the National Academy of Science of the United States of America, 103, 1342-1346. doi:10.1073/pnas.0503198103

[14] Kakunov, N.B. and Sulimova, E.I. (2005) Dynamics of geocryological conditions on territory of northern part Timan-Pechora oil-gas province for last 220 years and the forecast of their changes. Materials of Research-and-Production Conference Problems of Engineering-Geological Maintenance of Construction of Oil-and-Gas Complex Objects in Permafrost Zone, Moscow, 107-110.

[15] Perlshtein, G.Z., Pavlov, A.V. and Buiskikh, A.A. (2006) Changes of permafrost zone in conditions of modern cli- mate warming. Geoecology, 4, 305-312.

[16] Oberman, N.G. (2007) Some features of modern degradation of permafrost zone in the Pechora-Ural region. Materials of International Conference Cryogenic Resources of Polar Regions, 1, 96-99.

[17] Leibman, M.O., Moskalenko, N.G., Orekhov, P.T., et al. (2011) Interrelation of cryogenic and biotic components of geosystems in cryolithozone of the West Siberia along the "Yamal" transect. In: Kotlyakov, V.M., Ed., Polar Cryosphere and Continental Waters, Moscow-Saint-Petersburg, 171-192.

[18] Moskalenko, N.G., Vasiliev, A.A., Gashev, S.N., et al. (2006) Earth Cryosphere Institute, Moscow.

[19] Melnikov, E.S., Veisman, L.I., Moskalenko, N.G., et al. (1983) Landscapes of permafrost zone of the West Siberian gas province. Nauka, Novosibirsk.

[20] Andrianov, V.N., Kozlov, A.N. and Krizuk, L.N. (1973) Engineerin-geocryological conditions of pool of middle current Nadym River. Trudy of VSEGINGEO, 62, 79-89.

[21] Ponomareva, O.E. (2012) Climate change, frost action, and permafrost-related processes in the northern taiga region of West Siberia. Proceedings of the Tenth International Conference on Permafrost, 2, 343-347. 